\title{
The use of green walls and the impact on air quality and life standard
}

\author{
Małgorzata Wesołowska ${ }^{1, *}$, and Marta Laska ${ }^{1}$ \\ ${ }^{1}$ Wroclaw University of Science and Technology, Faculty of Environmental Engineering, \\ Wybrz. Wyspiańskiego 27, 50-370 Wrocław, Poland
}

\begin{abstract}
People living in urban areas are exposed to a number of threats related with dense urban tissue and high number of vehicles. These include air pollutions, traffic noise and high temperatures. In addition, large cities are struggling with high energy consumption for heating and cooling purposes. One of the possibilities to reduce the mentioned undesirable effects is the use of vegetation on the walls. Plants absorbs the pollutants of air, produced the oxygen, mounted on external walls create thermal insulation and positively affect the psychological aspect. Green walls can be used both indoors and outdoors. The article presents literature review on green walls, describes their benefits and presents the calculations SPBT and possible energy savings taking into account the transmission losses for small residential building.
\end{abstract}

\section{Introduction}

Large cities are struggling with many problems associated with dense urban tissue. Released heat and pollution in municipal and industrial processes, as well as the transformation of urban areas are anthropogenic factors that have the greatest impact on the city's climate [1]. The quality of life in urbanized areas is closely related to air parameters prevailing in the human environment. The most important are temperature, humidity and the degree of pollution level. This applies to both outdoor and indoor air. The number of deaths resulting from air quality is very high and amounts around the world about 800,000 annually by outdoor air pollution and 1.5 million annually by indoor air pollution [2].

Vegetation in urban areas is used due to a number of applications. First of all, it eliminates air pollution, which have direct effects on the air quality. It is also well known that plants positively affect the well-being of a person, and thus also his/her physical and mental health [3].

The ecological approach in construction industry around the world is constantly growing. This results in actions to reduce energy consumption, to rise comfort of human life and to reduce air pollution by creating green construction. A number of tools have been developed to help to assess whether a building can be described as green. For this purpose, a multi-criteria assessment was created. Currently, buildings in Poland can apply for five different certificates LEED (Leadership in Energy and Environmental Design), BREEAM

*Corresponding author: malgorzata.wesolowska@pwr.edu.pl 
(Building Research Establishment Environmental Assessment Method), DGNB (Deutsche Gesellschaft für Nachhaltiges Bauen), HQE (Haute Qualité Environmentale), WELL BUILDING STANDARD [4].

Table 1. $L E E D \circledR$ categories with credits (and associated points) that a green wall can help earn [5].

\begin{tabular}{l|l|c}
\hline \multirow{2}{*}{ Sustainable Sites } & $\begin{array}{l}\text { Credit 3: Integrated Pest Management, Erosion Control and Landscape } \\
\text { Management Plan (1 point) }\end{array}$ & $\sim$ \\
\cline { 2 - 3 } & Credit 5: Site Development: Protect or Restore Open Habitat (1 point) & + \\
\cline { 2 - 3 } & Credit 6: Stormwater Quantity Control (1 point) & $\cdot$ \\
\cline { 2 - 3 } & Credit 7.1: Heat Island Reduction: Non-Roof (1 point) & $\cdot$ \\
\cline { 2 - 3 } & Credit 8: Light Pollution Reduction (1 point) & $\sim$ \\
\hline Water Efficiency & Credit 3: Water Efficient Landscaping (1-5 points) & + \\
\hline Energy \& Atmosphere & Credit 1: Optimize Energy Efficiency Performance (1-18 points) & $\sim$ \\
\hline Materials \& Resources & Credit 3: Sustainable Purchasing: Facility Alterations and Additions (1 point) & + \\
\hline \multirow{2}{*}{$\begin{array}{l}\text { Indoor Environmental } \\
\text { Quality }\end{array}$} & $\begin{array}{l}\text { Credit 1.4: IAQ Best Management Practices: Reduce Particulates in Air Distribution } \\
\text { (1 point) }\end{array}$ & + \\
\cline { 2 - 3 } & Credit 2.1: Occupant Comfort: Occupant Survey (1 point) & + \\
\cline { 2 - 3 } & Credit 3.6: Green Cleaning: Indoor Integrated Pest Management (1 point) & + \\
\hline Innovation in Operations & Credit 1: Innovation in Operations (1-4 points) & + \\
\hline \multirow{2}{*}{$\begin{array}{l}\text { - Qualifies for LEED }{ }^{\circ} \text { credit } \\
+ \text { Positively effects LEED }\end{array}$} \\
$\begin{array}{l}\text { - No negalification } \\
\text { Used courtesy of greenovergrey.com. }\end{array}$
\end{tabular}

The most common around the world is LEED certification system, which distinguishes seven main categories, among which subcategories have been separated. Benefits resulting from the use of green walls and definition of categories are described Table 1. The vegetation on walls is included in two categories with total extra points of 36 to earn.

The most common forms of vegetation occurring in the city landscape are trees, shrubs and parks. Green roofs and walls are relatively new solutions for the development of urban space. In particular, vertical gardens are gaining popularity because their requirements are not so strict in comparison with green roofs.

\section{Possibility of use green walls in/on buildings}

The first modern introduction of green walls to the public area took place about 30 years ago. The French botanist Patric Blanc designed the first living wall system (Fig. 1. 4) [5]. It is made using dedicated boxes or panels placed on the entire surface of the wall in which the soil substrate and plants are located [6]. Internal constructions can be made of wood or plastic, because they are not exposed to external factors. A drip irrigation system is necessary to maintain vertical gardens. Vegetation for proper growth needs water and nutrients that are distributed through the fertilizer injector [5].

The elements of external constructions that are exposed to external factors, should be made of materials resistant to their influence, namely aluminum, galvanized steel or stainless steel [5].

An indispensable advantage of a living walls is that they can be made in any size and freely changed. The baskets and panels with small dimensions need no irrigation installation, therefore manual irrigation of plants is necessary in such issues.

The most popular green walls solution in external conditions is the green facade (Fig. 1-3). A characteristic feature of this type of solution is that the plants are climbing directly the building external walls or indirectly on ropes. The soil substrate is located only in one 
place - at the foot of the wall where the greenery is planted or in dedicated planter boxes. This system is made using vines such as ivy.
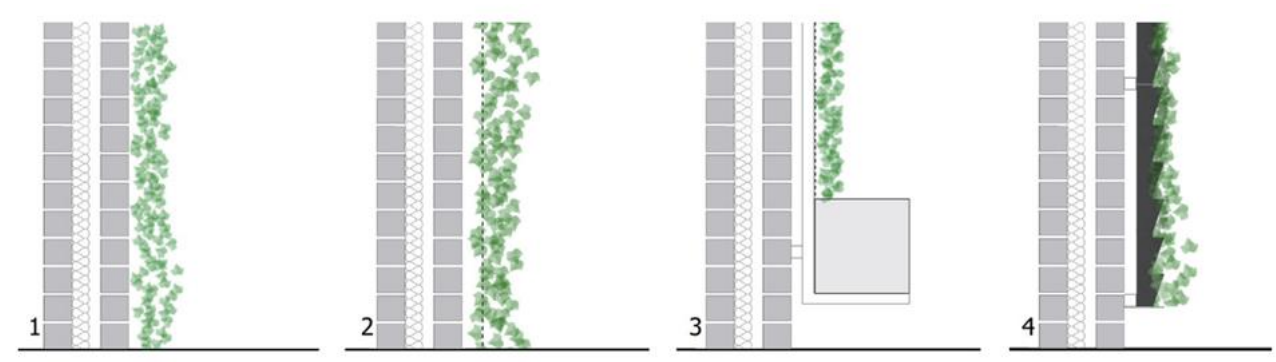

Fig. 1. Typology of green walls 1. Direct green façade, 2. Indirect green facade, 3. Indirect green façade combined with planter boxes, 4 . Living wall systems [6].

\section{Using green walls as health aspects}

The positive effect of vegetation on humans has been proven a long time ago. Vegetation uses absorption to remove gaseous pollutants [7] and produces an oxygen. However, this is just one of many possibilities and positive aspects of their application. Green walls can affect the spread of harmful substances and isolate places exposed to sound pollution. In addition, the flora affects humans directly, improving their well-being [3].

\subsection{Noise reduction}

One of the pollution in the urban area is noise. Over $44 \%$ of the population living in the European continent is exposed to traffic noise of $44 \mathrm{~dB}$. It is bothersome especially in the case of dense urban tissue and along fast roads [8].

There are many literature sources [9-11] in which noise reduction using urban green, roofs and walls is described. Vegetation has one of the greater coefficients of sound absorption compared to other building materials. For a roof covered with a biological layer of $12 \mathrm{~cm}$ and $20 \mathrm{~cm}$, the reduction of unwanted noise level is $40 \mathrm{~dB}$ and $50 \mathrm{~dB}$, respectively $[11,12]$. The noise reduction can be of a different level when using various plants and thicknesses of soil substrate. The scientists from Singapore [8] found out that the use of green facades can reduce the local sound intensity up to $10 \mathrm{~dB}$. Other research [13] describes the experiment in laboratory conditions that resulted the noise reduction of $15 \mathrm{~dB}$.

\subsection{Improving an indoor air quality}

External air pollution is the cause of premature death. According to WHO, more than 4.2 million people died worldwide in 2016 [14]. The most harmful substances for our health occurring in the urban area are suspended dust, whose aerodynamic diameter is less than $10 \mu \mathrm{m}\left(\mathrm{PM}_{10}\right)$, nitrogen dioxide $\left(\mathrm{NO}_{2}\right)$, sulfur dioxide $\left(\mathrm{SO}_{2}\right)$, ozone [15] and carbon compounds $\left(\mathrm{CO}, \mathrm{CO}_{2}\right)$ and ultrafine particles (UFP, $\left.<100 \mathrm{~nm}\right)$ [7].

Research $[3,7,16]$ shows that green walls can reduce the level of air pollution and thus improve the indoor air quality threefolds:

a) absorption of gaseous pollutants through stomata in plant leaves,

b) settling / sticking solid particles to the leaf surface,

c) passive accumulation of pollutants on the plant's root-soil system [17]. 
These process can be harmful to plants. Chemical processes in which the assimilation of gases $\left(\mathrm{CO}_{2}, \mathrm{NO}_{2}, \mathrm{SO}_{2}\right)$ may cause the formation of toxic compounds, degrading cells and plant tissues [16] therefore to create green wall solutions more resistant species need to be chosen. In addition, the atmospheric particulate matter are adsorbed on the surface layer and it the long term can damage plants and under the strong wind and rain conditions, may return to the atmosphere or be absorbed into the soil [3].

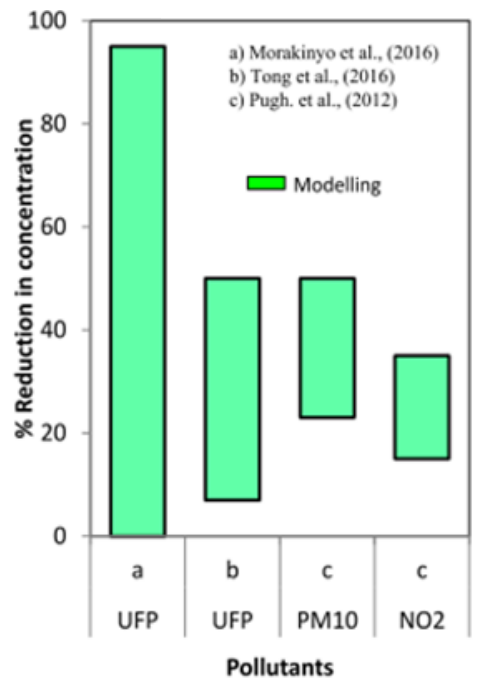

Fig. 2. Percentage of reduction in pollutant concentration with green walls [7].

The percentage of pollution reduction differs depending of the type of chemical compounds being analyzed. Carbon dioxide, in concentrations above 1000ppm (by volume) in rooms, can lead to health problems [18]. Vegetation uses the photosynthesis process. It absorbs $\mathrm{CO}_{2}$ from the environment at the same time releasing $\mathrm{O}_{2}$, which is associated with the improvement of air quality [19]. Depending on the plants used, weather conditions and the wall orientation, the degree of $\mathrm{CO}_{2}$ reduction may vary. Using vegetation on the walls, which are exposed on proper sun lighting, the $\mathrm{CO}_{2}$ content in the air can be reduced by $250 \mu \mathrm{mol} \mathrm{m} / \mathrm{s}$ [18]. Fallow in the Fig. 2, which presents modeled values, the particulate matter $\mathrm{PM}_{10}$ level may be reduced up to $50 \%$, while the amount of $\mathrm{NO}_{2}$ in the air may be decreased about $60 \%$ [7]. The largest reduction can be observed for the smallest particles, even up to $95 \%$.

Vegetation maintains the moisture in the closest surrounding. This may cause moisture trapping in the walls and the condensation of water vapor on the surface of the wall [20] increasing the risk of mold occurrence. Therefore, attention should be paid to the protection of surfaces exposed to condensation and to ensure adequate care of plants.

\subsection{Pollutant dispersion}

Green walls in the urban area are also important in the case of the spread of pollutants, which is presented in the article [7]. Fig. 3 and Fig. 4 present two ways of the use of vegetation on the walls, in the street canyon and in the cross section of the open road.

The use of vegetation on the open road section has an impact on the speed of air and at the same time on the rate of pollution spreading (Fig. 3). The most effective solution is to make green screens (Fig. 3c). In particular, in areas where increased pedestrian traffic occurs. 
People who are near the road lane are not directly exposed to pollution, which is the result of fuel combustion in cars and raised from the road through the movement of car wheels.

When the road lane is in close proximity to the buildings, both the buildings themselves and the area around them are exposed to pollution, and thus the habitants. The use of vegetation can change the nearby conditions, as presented at Fig. 4. In addition, the use of green walls on the buildings protects their façades from physical damages and reduces the negative phenomenon of Urban Heat Islands [5, 21].

(a) Road with no vegetation barrier
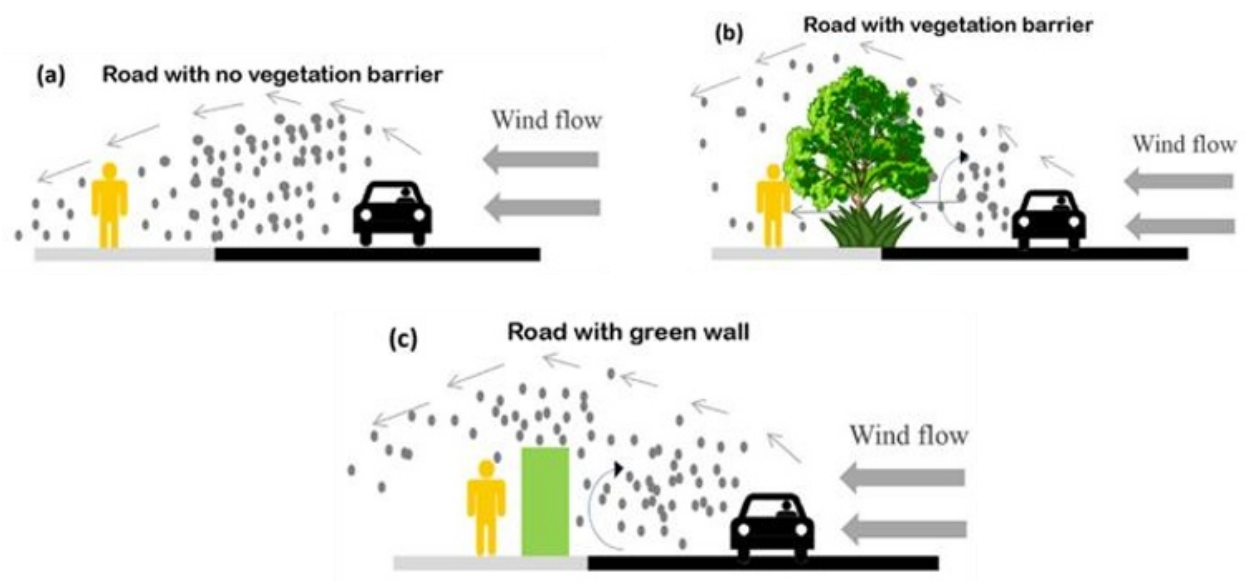

Fig. 3. Dispersion patterns of road pollutants under open road configurations (a) without vegetation barrier (b) with vegetation, and (c) with green wall [7].
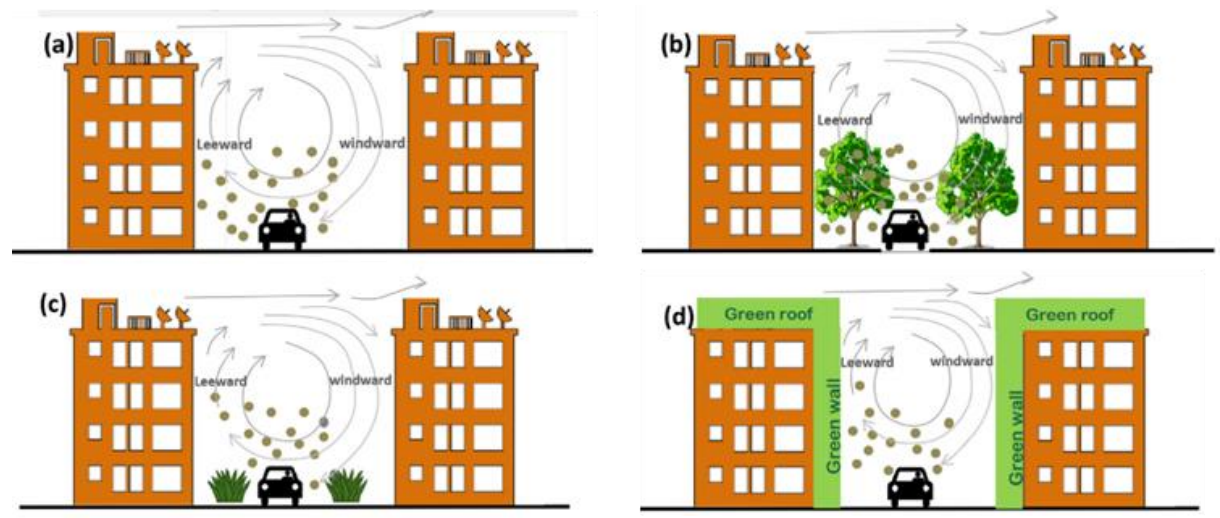

Fig. 4. Description of flow and pollutant dispersion patterns in a street canyon with and without different types of vegetation: (a) vegetation free street canyon, (b) street canyon with trees, (c) street canyon with hedges, and (d) street canyon with green roof and green wall [7].

\subsection{Well-being}

According to a study [22] people spend about $90 \%$ of their time indoors. External air pollution affects the quality of the indoor air. The literature [5] proves that conditions in rooms can be even ten times worse than the outside. Contaminants can enter to the building from outside through windows, hatchways and leaks or can be produced internally by people or finishing materials. Undesirable substances may lead building users to discomfort and/or be related to their health problems described as sick building syndromes [5, 23]. This can be 
reduced by green walls. Research $[5,24]$ show that closeness to nature reduces obesity and reduces the likelihood of having a heart attack by lowering blood pressure. In addition, the proximity of plants in the work environment improves the efficiency of employees, speeds up the reaction time by up to $12 \%$ and helps them to focus [5]. The improvement of wellbeing, the feeling of relaxation and better concentration are also a result of the interaction of living greenery.

\section{Cost and benefits installation of green walls}

The use of vertical gardens gives a number of benefits also economic. Research [5] indicates that prices of properties with gardens, green roofs and walls are approximately $15 \%$ higher than similar without greenery [5].

\subsection{Installations costs}

In section 2, green wall implementation systems are presented. Their differences result from the construction and complexity of solutions and from the vegetation used. This, in turn, causes differences in the price of execution and installation. The simplest and the cheapest one is the direct green facade. For its implementation, it is only necessary to determine the place of lichen vegetation and plant it at the foot of the barrier. The cost of making a green direct facade varies between 30 and $45 \mathrm{EURO} / \mathrm{m}^{2}$ [6]. A more expensive solution is the indirect green facade, which is valued at $40-75 \mathrm{EURO} / \mathrm{m}^{2}$. The higher cost results from the elements necessary for this kind of green wall. In this case, steel structures should be used [6]. Another solution is the indirect green facade, in which the soil substrate is located in a dedicated box. The material of the container affects directly the price of a square meter of green wall. The price of a system made of plastic costs from 100 to $150 \mathrm{euro} / \mathrm{m}^{2}$, when for a system made of zinc-coated steel even up to $800 \mathrm{euro} / \mathrm{m}^{2}$ [6]. The most expensive and the most complex solution is the living wall. There is a technology that uses panels or special baskets filled with soil substrate. As a result, the soil surface in which the planting plants are located is close to the wall surface. Its use requires a number of elements. The most cost-intensive is the implementation of an irrigation installation and all supporting constructions. The cost of planting with all the necessary elements in the case of a living wall is from 400 to $1200 \mathrm{EURO} / \mathrm{m}^{2}$ depending on the materials used and the type of vegetation [6].

\subsection{Energy savings}

An important element, strongly influencing the operational costs of the building, is the level of its energy consumption, therefore lowering the energy usage can significantly reduce the energy bills. Literature [21] confirms that the green façade influences the reduction of wall heat transfer coefficient. Depending on initial raw construction of the external wall, the additional plant layer may reduce the heat transfer coefficient even by a dozen or so percent. The data given in [21] concerns a cold-green plant layer with the thickness of $35 \mathrm{~cm}$. An additional aspect of the use of green facades is related to the policy of European cities aimed at intensifying the development of green areas in cities and encouraging residents to do so. In order to achieve this goal in Wroclaw, the City Council, adopted a resolution [25], in which city residents are exempt from property tax. In order to assess the impact of the green façade on the energy consumption and related costs, the calculations for an existing building located in Wroclaw, Poland were made. The outcome is presented below. The facility is located in the city center, among buildings of similar height. External walls are made of solid brick on 
the mortar with heat transfer coefficient of $1.25 \mathrm{~W} / \mathrm{m}^{2} \mathrm{~K}$. This multifamily building consist of 4 floors. The plan area of the building is $144 \mathrm{~m}^{2}$. The vegetation was assumed to be on all buildings external walls. The calculations shows that the annual energy saving for heating, determined only on the basis of a reduction in the heat transfer coefficient, will amount to less than 200 PLN (Fig. 5).

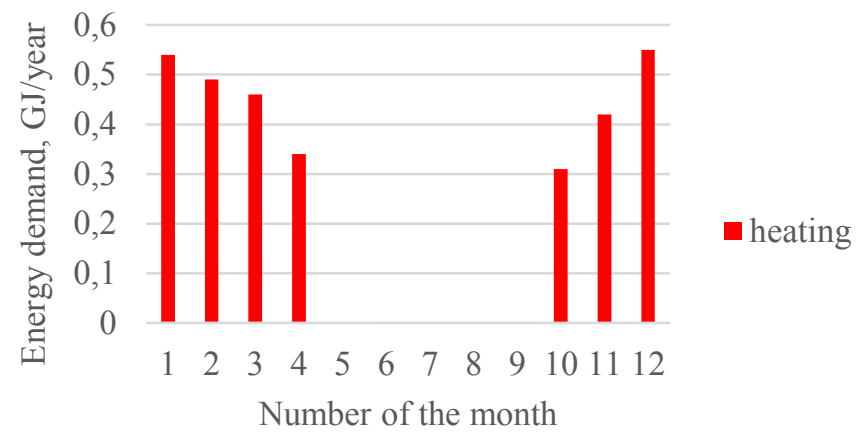

Fig. 5. Annual energy savings after adding of greenery at the façade and taking into account only static losses through the building envelope.

The statistical economic indicator SPBT (Simply Pay Back Time) was used to determine the simple payback period of implementation greenery. SPBT is based on the assumption a constant value of money throughout the payback period and is described by the equation (1) as follows:

$$
S P B T=\frac{N_{u}}{\sum_{n} \Delta Q_{r U}}
$$

$\mathrm{Nu}$ - planned costs of works related to the reduction of heat transfer losses for the total area of the selected wall/with the replacement of window and door joinery [PLN] $\triangle Q r U$ - annual energy savings resulting from the use of the improvement [PLN/year].

The investment cost for analyzed building with direct green façade was determined fallowing the data published in the literature [6]. Its value amounts to 6,000 PLN. Taking into account the annual energy savings and the aforementioned local law, the payback time (SPBT) for this investment was calculated to be 13 years.

\section{Summary}

Nowadays big cities struggle with urban heat islands, bad quality of outdoor air and high energy costs in buildings located in dense urban tissue. The perspective to use the vegetation on the external walls seem to have enough advantages, described in the paper, to be applied into everyday city and citizens life. Apart those connected with the air quality green facades have a positive effect on the level of buildings energy consumption and thus it is also derisible as the additional element of existing buildings. The purpose of this paper was to point out pros of using plants as the external wall covering, and to check the level of savings in heat energy consumption on the example of uninsulated building. The reduction of the heat transfer losses for analyze premise is not significant. The simple pay back time (SPBT) reaches quite high value that is lowered by the land tax exemption (guaranteed by the local city regulations). However it is important to underline, that there was no shading effect taken into account nor additional cooling effect during the summer was calculated. Apart this 
outcome, using the greenery on buildings is constantly desired action by the city governors and should be considered and deeply investigated in terms of utilization of buildings located in dense urban tissue.

The work can be presented on the conference thanks to the founds of the Faculty of Environmental Engineering, Wroclaw University of Science and Technology, Poland. Ref No. 0401/0055/18.

\section{References}

1. A. Dubicki, M. Dubicka, M. Szymanowski, Środowisko Wrocławia - Informator, 9-25 (2002)

2. D. Campbell-Lendrum, C. Corvalá,. J. Urban Heal. Bull. New York Acad. Med. 84 (2007)

3. B. A. Currie, B. Bass, Urban Ecosyst. 11, 409-422 (2008)

4. https://plgbc.org.pl/certyfikacja-wielokryterialna/leed/ (Accessed: $25^{\text {th }}$ February 2019)

5. M. Weinmaster, J. of Green Building, 4 (2009)

6. K. Perini, P. Rosasco, Build. Environ. 70, 110-121 (2013)

7. K. V. Abhijith, Atmospheric Environment 162, 71-86 (2017)

8. N. H. Wong, Build. Environ. 45, 411-420 (2010)

9. G. Pérez, Appl. Acoust. 110, 218-226 (2016)

10. J. Newton, Building Greener: Guidance on the Use of Green Roofs, Green Walls and Complementary Features on Buildings (CIRIA, 2007)

11. N. Dunnett, N. Kingsbury, Planting green roofs and living walls (Timber Press, 2008)

12. S. W. Peck, C. Callaghan, Greenbacks from green roofs: forging a new industry in Canada status report on benefits, barriers and opportunities for green roof and vertical garden technology diffusion (1999)

13. Z. Azkorra, Appl. Acoust. 89, 46-56 (2015)

14. Mortality and burden of disease from ambient air pollution (WHO, 2018)

15. T. A. M. Pugh, A. R. MacKenzie, J. D. Whyatt, C. N. Hewitt, Environ. Sci. Technol. 46, 7692-7699 (2012)

16. J. Mori, F. Ferrini, A. Saebo, Italus Hortus 25, 13-22 (2018)

17. B. C. Wolverton, A. Johnson, K. Bounds, Interior Landscape Plants for Indoor Air Pollution Abatement (National Aeronautics and Space Administration, 1989)

18. F. Torpy, M. Zavattaro, P. Irga, Air Qual. Atmos. Heal. 10, 575-585 (2017)

19. F. Brilli, Trends Plant Sci. 23, 507-512 (2018)

20. E. Trzaskowska, Teka Kom. Arch. Urb. Stud. Kraj. - OL PAN VI, 110-121 (2010)

21. D. Fabianowski, Zieleń Miejska, 8 (2011)

22. S. L. Stockham, M. A. Scott, Am. Phys. Soc. 52-53 (2008)

23. S. M. Joshi, Indian J. Occup. Environ. Med. 12, 61-4 (2008)

24. T. Safikhani, A. M. Abdullah, D. R. Ossen, M. Baharvand, Renew. Sustain. Energy Rev. 40, 450-462 (2014)

25. Uchwała Rady Miejskiej Wrocławia w sprawie zwolnień od podatku od nieruchomości powierzchni użytkowych lokali mieszkalnych w ramach projektu intensyfikacji powstawania terenów zieleni w obrębie Miasta Wrocławia, XV/268/15 